\title{
Pemanfaatan Bahan Nabati Lokal Berefek Pestidida untuk Mengendalikan Hama Cylas formicarius pada Tanaman Ubi Jalar
}

(Utilization of Local Vegetable Materials Effecting Pesticides to Control Cylas formicarius Pests in Sweet Potatoes)

\author{
Nina Jeni Lapinangga ${ }^{1}$ dan Yosefus F. da Lopez ${ }^{2}$ \\ ${ }^{1}$ Jurusan Tanaman Pangan dan Hortikultura, Politani Kupang \\ ${ }^{2}$ Staf Pengajar pada Jurusan Pertanian Lahan Kering, Politani Kupang \\ *Email korespondensi: ninalapinangga@yahoo.co.id
}

Diterima 06 April 2018 / Disetujui 20 Juni 2018

\begin{abstract}
Sweet potato is one of the commodities currently being developed in Timor Tengah Selatan District, but its productivity is far lower than national productivity. The cause is a pest attack Cylas formicarius. The use of chemical insecticides carried out by farmers now can cause a variety of negative influences so that it is necessary to find other alternatives to control pests or by looking for substitutes for chemical pesticides. One of these substitutions uses vegetable pesticides from plants. Nature in Timor Tengah Selatan District (TTS) provides many ingredients that are provided as vegetable pesticides. For example neem (Azadirachta indica), babadotan (geratum conyzoides), soursop (ㅅnnona muricata), anona (Annona squamosa), kenikir (Tagetes erecta), papaya (Carica papaya), and sirih hutan (Piper caducibracteum). However, overcoming the problem of these substances to control the pest Cylas formicarius has not been understood. This study discusses vegetable pesticides against mortality of Cylas formicarius pests. The results of this study are expected to be the basis for farmers in determining the technique of controlling Cylas formicarius which is environmentally friendly.Based on the results of the study, it can be denied that the aid of vegetable pesticides to the highest mortality of Cylas formicarius pests to the lowest was achieved, namely: leaves of mimba at 97.5\%; soursop leaves 92.5\%; anona leaves $87.5 \%$; betel leaves at $82.5 \%$; babadotan leaves at $67.5 \%$; kenikir leaves of 47.5\%; and papaya leaves by 45\%. Freed to use neem leaves, soursop leaves, anona leaves, betel leaves, and babadotan leaves to control Cylas formicarius pests because they can cause larval mortality above $50 \%$ in the laboratory.
\end{abstract}

Keywords: entomopathogenic fungi, vegetable insecticides, local isolates, Cylas formicarius, sweet potatoes.

\section{ABSTRAK}

Ubi jalar merupakan salah satu komoditas yang saat ini sedang dikembangkan di Kabupaten Timor Tengah Selatan, namun produktivitasnya jauh lebih rendah dari pada produktivitas nasional. Penyebabnya yaitu serangan hama Cylas formicarius. Penggunaan insektisida kimia yang dilakukan oleh petani saat ini dapat menimbulkan berbagai pengaruh negatif sehingga perlu dicari alternatif lain untuk mengendalikan hama atau dengan mencari substitusi pestisida kimiawi. Salah satu substitusi tersebut adalah dengan menggunakan pestisida nabati yang berasal dari tumbuh-tumbuhan. Alam di Kabupaten Timor Tengah Selatan (TTS) menyediakan banyak bahan yang berpotensi sebagai pestisida nabati. Misalnya mimba (Azadirachta indica), babadotan (Ageratum conyzoides), sirsak (Annona muricata), anona (ㅅnnona squamosa), kenikir ( Tagetes erecta), pepaya (Carica papaya), dan sirih hutan ( Piper caducibracteum). Namun, efektivitas bahan-bahan nabati tersebut untuk mengendalikan hama Cylas formicarius belum diketahui. Penelitian ini bertujuan untuk mengetahui efektivitas

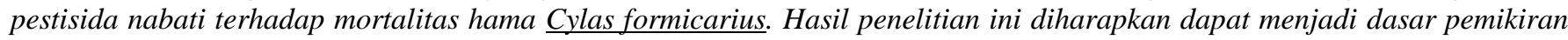
bagi petani dalam menentukan teknik pengendalian hama Cylas formicarius yang ramah lingkungan. Berdasarkan hasil penelitian maka dapat disimpulkan bahwa efektivitas pestisida nabati terhadap mortalitas hama Cylas formicarius tertinggi sampai terendah berturut-turut yaitu: daun mimba sebesar 97.5\%; daun sirsak sebesar 92.5\%; daun anona 87.5\%; daun sirih sebesar 82.5\%; daun babadotan sebesar 67.5\%; daun kenikir sebesar 47.5\%; dan daun pepaya sebesar 45\%. Disarankan untuk menggunakan daun mimba, daun sirsak, daun anona, daun sirih, dan daun babadotan untuk mengendalikan hama Cylas formicarius karena mampu menyebabkan mortalitas larva di atas $50 \%$ pada kondisi laboratorium.

Kata kunci : jamur entomopatogen, insektisida nabati, isolat lokal, Cylas formicarius, ubi jalar.

\section{PENDAHULUAN}

Sebagai pangan alternatif sumber karbohidrat pengganti beras, ubi jalar dapat dikembangkan untuk memperkuat ketahanan pangan masyarakat. Kabupaten Timor Tengah Selatan (TTS) termasuk daerah yang saat ini sedang menggalakan penanaman ubi jalar. Produktivitas ubi 
jalar di TTS pada tahun 2014 sebesar 130,20 ku/ha, jauh lebih rendah dari pada produktivitas nasional yaitu sebesar $151,97 \mathrm{ku} / \mathrm{ha}$ (BPS TTS, 2014). Faktor-faktor yang mempengaruhi hasil ubi jalar antara lain adalah umur dan kultivar tanaman, kesuburan tanah, tinggi tempat penanaman, iklim (musim tanam), serta gangguan hama dan penyakit.

Beberapa spesies serangga menjadi hama pada ubi jalar, namun yang paling merusak adalah Cylas formicarius, disebut juga kumbang penggerek umbi atau hama lanas. Hama ini selain merusak umbi di pertanaman, juga menyerang umbi yang telah disimpan di gudang (Nonci, 2005; Powell, 2001). Serangan hama ini dapat menyebabkan kehilangan hasil antara 10 - 80 \% (Capinera, 2012; Kalshoven, 1981). Umumnya larva, pupa, dan imago tinggal di dalam umbi sehingga kerusakan di bagian dalam umbi sangat merugikan. Baik larva maupun imago, keduanya sama-sama menimbulkan kerusakan (Powell, 2001). Kerusakan dapat dilihat pada permukaan umbi, adanya lubang-lubang kecil dan mengeluarkan bau busuk yang khas. Umbi yang telah terserang tidak layak lagi dikonsumsi karena apabila dikonsumsi maka akan berbahaya bagi kesehatan hati dan paru-paru (Supriyatin dalam Romadhon, 2008). Kotoran hama yang terdapat pada bagian-bagian umbi yang telah rusak juga menyebabkan rasa pahit (Zuraida et al., 2005).

Tindakan pengendalian $C$. formicarius yang sering dilakukan oleh petani adalah dengan menggunakan insektisida kimia, padahal penggunaan insektisida kimia yang berlebihan atau tidak bijaksana akan mengakibatkan hama menjadi resisten, timbulnya hama baru dan yang lebih penting lagi terbunuhnya musuh-musuh alami seperti parasitoid dan predator yang mampu menekan populasi hama. Mengingat dampak negatif yang ditimbulkan oleh pestisida maka perlu dicari alternatif lain untuk mengendalikan hama atau dengan mencari substitusi pestisida kimiawi. Salah satu substitusi tersebut adalah dengan menggunakan pestisida nabati yang berasal dari tumbuh-tumbuhan.

Saat ini telah diketahui lebih kurang 2.400 jenis tumbuhan di dunia yang mengandung bahan pestisida dan 100 jenis lainnya mempunyai potensi untuk dikembangkan sebagai pestisida nabati (Grainge dan Ahmed, 1988). Sebagai negara yang terletak di daerah tropika, Indonesia mempunyai sumber daya hayati yang melimpah termasuk di dalamnya jenis-jenis tumbuhan yang mengandung bahan aktif pestisida nabati (Heyne, 1987).

Alam di Kabupaten Timor Tengah Selatan (TTS) menyediakan banyak bahan yang berpotensi sebagai pestisida nabati. Misalnya mimba (Azadirachta indica), babadotan (Ageratum conyzoides), sirsak (Annona muricata), anona (Annona squamosa), kenikir (Tagetes erecta), pepaya (Carica papaya), dan sirih hutan (Piper caducibracteum). Namun, efektivitas bahan-bahan nabati tersebut untuk mengendalikan hama Cylas formicarius belum diketahui.

Melihat besarnya potensi sumberdaya hayati jenisjenis tumbuhan lokal tersebut untuk dikembangkan sebagai sumber pestisida nabati dimasa yang akan datang maka hasil dari penelitian ini diharapkan dapat dijadikan sebagai dasar untuk mengembangkan jenis-jenis tumbuhan lokal tersebut menjadi ramuan pestisida nabati untuk pengendalian hama Cylas formicarius. Penelitian ini bertujuan untuk mengetahui efektivitas pestisida nabati terhadap mortalitas hama Cylas formicarius. Hasil penelitian ini diharapkan dapat menjadi dasar pemikiran bagi petani dalam menentukan teknik pengendalian hama Cylas formicarius yang ramah lingkungan.

\section{METODE PENELITIAN}

Bahan nabati yang digunakan yaitu daun mimba, daun babadotan, daun sirsak, daun anona, kenikir, daun pepaya, dan daun sirih hutan. Pembuatan tepung dari bahan nabati tersebut mengikuti prosedur Brotodjojo (2002). Daun yang disiapkan tidak terlalu muda dan tidak terlalu tua atau daun ke tiga dari pucuk. Bahan-bahan yang diperoleh dari wilayah di Kabupaten TTS tersebut dikeringanginkan selama \pm 5 hari, lalu ditumbuk dengan mortar sampai halus. Bahan yang sudah dihaluskan lalu dioven pada suhu $40-45$ ${ }^{0} \mathrm{C}$ sampai mendapatkan berat kostan. Setelah beratnya konstan, bahan tersebut dihaluskan lagi dengan blender dan diayak dengan ayakan 200 mesh. Selanjutnya, bahan dibuat ekstrak dengan pelarut aquadest sesuai dengan konsentrasi yang dibutuhkan yakni $10 \%$ dan sudah direndam selama 24 jam. Konsentrasi $10 \%$ diperoleh dengan cara memasukan bahan yang telah halus sebanyak 10 gram lalu dimasukkan ke dalam gelas ukur $100 \mathrm{ml}$ kemudian ditambahkan aquadest sampai batas tera.

\section{Uji efektivitas bahan nabati}

Pengujian dilakukan dengan cara meletakkan 10 ekor larva Cylas formicarius instar tiga ke dalam gelas bening yang berisi $10 \mathrm{ml}$ eksktrak bahan nabati sesuai perlakuan. Potongan umbi ubi jalar dimasukkan sebagai pakan larva. Penelitian ini menggunakan Rancangan Acak Lengkap (RAL), dengan delapan perlakuan (7 jenis bahan nabati dan 1 kontrol) dan empat ulangan. Pengamatan mortalitas larva dilakukan 5 kali dengan interval pengamatan setiap 6 jam sekali. Pengamatan dilakukan dengan mencatat jumlah larva yang mati pada masingmasing perlakuan.

Persentase mortalitas larva dihitung dengan menggunakan rumus :

$$
\mathrm{M}=\mathrm{A} / \mathrm{D} \times 100 \%
$$

Keterangan : $\mathrm{M}=$ Persentase mortalitas

$$
\begin{aligned}
& A=\text { Jumlah serangga yang mati terinfeksi } \\
& D=\text { Jumlah serangga yang diuji }
\end{aligned}
$$

Persentase mortalitas yang diperoleh kemudian dikoreksi dengan menggunakan rumus Abbott's (Finey, 1971) yaitu:

$$
\mathrm{Pt}=\frac{\mathrm{P}_{0}-\mathrm{P}_{\mathrm{c}}}{100-\mathrm{P}_{\mathrm{c}}} \times 100 \%
$$

Dimana: $\mathrm{Pt}=$ Persentase kematian terkoreksi

Po $=$ Persentase kematian teramati

$\mathrm{Pe}=$ Persentase kematian kontrol 


\section{HASIL DAN PEMBAHASAN}

Mortalitas larva Cylas formicarius akibat pemberian beberapa bahan nabati pada tanaman ubi jalar tertera pada Tabel 1. Berdasarkan Tabel 1, mortalitas larva $C$. formicarius tertinggi pada pengamatan pertama (6 jam setelah aplikasi) terdapat pada perlakuan daun mimba yaitu sebesar 5\% diikuti oleh daun sirsak dan anona sebesar $2.5 \%$. Sedangkan pada perlakuan lainnya tidak ditemukan larva yang mati. Mortalitas larva $C$. formicarius tertinggi pengamatan kedua (12 jam setelah aplikasi) terdapat pada perlakuan pestisida nabati daun sirsak dan mimba yaitu sebesar $17.5 \%$, diikuti mortalitas pada daun sirih dan anona yaitu sebesar $12.5 \%$, daun babadotan sebesar $7.5 \%$, daun kenikir dan daun pepaya sebesar $2.5 \%$ dan kontrol $0 \%$. Pengamatan yang ketiga (18 jam setelah aplikasi), mortalitas larva $C$. formicarius tertinggi terdapat pada perlakuan daun mimba $(40 \%)$, diikuti daun sirsak $(37.5 \%)$, daun sirih dan anona $(32.5 \%)$, daun kenikir dan pepaya $(12,5 \%)$, kontrol (0\%). Dua puluh empat (24) jam setelah aplikasi (pengamatan keempat), mortalitas larva dari tertinggi sampai terendah berturut-turut yaitu daun mimba (67.5\%), daun sirsak $(62.5 \%)$, daun sirih dan daun anona (55\%), daun babadotan $(42.5 \%)$, daun kenikir $(27.5 \%)$, daun pepaya (25\%), dan kontrol (0\%). Pengamatan yang terakhir (30 jam setelah aplikasi), mortalitas larva tertinggi pada perlakuan daun mimba yaitu sebesar $97.5 \%$, diikuti daun sirsak sebesar $92.5 \%$, daun anona $87.5 \%$, daun sirih $82.5 \%$, daun babadotan $62.5 \%$, daun kenikir $(47.5 \%)$, daun pepaya $45 \%$, dan kontrol $0 \%$.

Berdasarkan pengamatan yang dilakukan, perilaku larva $C$. formicarius instar III setelah aplikasi menunjukan perilaku gelisah, diam ditempat (tidak bergerak) sampai akhirnya mengalami kematian. Mortalitas larva $C$. formicarius tertinggi pada setiap perlakuan (kecuali kontrol) terdapat pada pengamatan terakhir (30 jam setelah aplikasi). Menurut Kardinan (2005), pestisida nabati terutama yang bekerja sebagai racun perut biasanya membutuhkan waktu untuk dapat mematikan serangga. Kemungkinan karena ekstrak bahan nabati membutuhkan waktu yang cukup untuk sampai ke saluran pencernaan serangga. Zat-zat yang terdapat dalam bahan nabati masuk kedalam pencernaan melalui makanan akan diserap oleh dinding usus, sehingga senyawa aktif dari bahan nabati mulai bekerja ketika sampai di usus. Oleh karena itu, dapat dikatakan bahwa waktu pengamatan mempengaruhi mortalitas larva $C$. formicarius instar III. Semakin lama waktu pengamatan maka semakin meningkat mortalitas larva $C$. formicarius instar III.

Tujuh (7) jenis bahan nabati yang digunakan merupakan racun perut (Asikin et al., 2002), karena reaksi racun dari masing-masing bahan nabati ini dapat dilihat setelah larva dari hama $C$. fomicarius tersebut memakan umbi ubi jalar yang telah diberi perlakuan ekstrak cair dari masing-masing bahan nabati tersebut. Menurut Asikin et al., (2002), bahwa bahan tumbuhan yang dapat digunakan sebagai bahan insektisida nabati pada umumnya merupakan racun perut.

Menurut Kardinan (2005) daun dan biji sirsak berperan sebagai insektisida, larvasida, reppelent, antifeedant, dengan cara kerja sebagai racun perut dan racun kontak. Zat-zat yang terdapat dalam daun A. muricata masuk ke dalam pencernaan melalui makanan akan diserap oleh dinding usus, sehingga senyawa aktif dari ekstrak daun $A$. muricata yaitu tanin dan acetogenin mulai bekerja ketika sampai di usus. Tanin menghambat aktivitas enzim pada saluran pencernaan serangga sedangkan senyawa acetogenin meracuni sel-sel saluran pencernaan akhirnya serangga uji mengalami kematian. Pada konsentrasi tinggi, senyawa acetogenin memiliki keistimewaan sebagai antifeedant. Dalam hal ini, serangga tidak lagi memakan bagian tanaman yang disukainya. Sedangkan pada konsentrasi rendah, bersifat racun perut yang biasa mengakibatkan serangga hama mengalami kematian.

Claus (1961) dalam Padang (2001), menambahkan bahwa tanaman A. muricata mengandung isoquanolin yang termasuk golongan alkaloid. Alkaloid merupakan senyawa yang bersifat basah yang terdapat dalam tanaman tertentu dalam jumlah yang relatif kecil dan mempengaruhi aktivitas biologi. Lebih lanjut Panda dan Gurdev (1995), menyatakan bahwa isoquanolin alkaloid merupakan senyawa yang menyebabkan serangga tidak makan, dalam hal ini bersifat sebagai antifeedant. Ditambahkan oleh Dadang (1999), bahwa antifeedant merupakan senyawa yang secara substansi tidak memberikan penolakan aktivitas makan tetapi memberikan rasa ketidaksukaan pada serangga.

Senyawa aktif utama tanaman anona (Anonna squamosa) yang berefek pestisida adalah annonain yang terdiri dari squamosin dan asimisin yang termasuk senyawa asetoginin dan memiliki efek kontak cukup baik terhadap serangga. Selain itu berperan sebagai racun yang dapat menolak serangga, menghambat serangga yang mau meletakkan telurnya pada daun tanaman. Racun ini juga berperan mengurangi nafsu makan serangga.

Mortalitas larva $C$. formicarius disebabkan oleh racun yang terkandung dalam daun sirih hutan terutama kandungan minyak atsiri, alkaloid, tanin, flavonoid, dan terpenoid. Sirih hutan memiliki aroma yang sangat tajam, disebabkan adanya kavikol dan betlephenol yang terkandung dalam minyak atsiri (Moeljanto dan Mulyono, 2003). Minyak atsiri dan flavonoid bertindak sebagai racun pernapasan. Menurut (Mulyantana, 2013) minyak atsiri dalam daun sirih bersifat racun yang kerjanya menghambat aktivitas respirasi serangga sehingga menyebabkan kematian secara lambat. Cara kerja minyak atsiri adalah masuk ke dalam tubuh $C$. formicarius melalui sistem pernapasan kemudian menimbulkan kelayuan pada saraf serta kerusakan sistem pernapasan dan mengakibatkan larva $C$. formicarius tidak bisa melakukan respirasi sehingga akhirnya mati. Larva yang terkena pestisida nabati daun sirih hutan tampak layu, hini disebabkan kandungan senyawa aktif dari daun sirih hutan. Menurut Yenie et al. (2013), tanin yang terkandung dalam daun sirih hutan dapat menyusutkan jaringan dan menutup struktur protein pada kulit dan mukosa. Aplikasi pestisida nabati daun sirih hutan menyebabkan umbi ubi jalar terasa pahit, sehingga tidak disukai oleh larva $C$. formicarius. Akibatnya larva $C$. formicarius tidak mau makan dan akhirnya mati karena kelaparan. Rasa pahit dari daun sirih disebabkan adanya 
Tabel 1. Persentase Mortalitas Larva Cylas formicarius (\%)

\begin{tabular}{clccccc}
\hline \multirow{2}{*}{ No. } & & \multicolumn{5}{c}{ Akumulasi Persentase Mortalitas Larva (\%) pada Jam Setelah Aplikasi } \\
\cline { 3 - 6 } & & 6 & 12 & 18 & 24 & 30 \\
\hline 1 & Kontrol & 0 & 0 & 0 & 0 & 0 \\
2 & Daun Pepaya & 0 & 2.5 & 12.5 & 25 & 45 \\
3 & Daun Sirih & 0 & 12.5 & 32.5 & 55 & 82.5 \\
4 & Daun Anona & 2.5 & 12.5 & 32.5 & 55 & 87.5 \\
5 & Daun Kenikir & 0 & 2.5 & 12.5 & 27.5 & 47.5 \\
6 & Daun Babadotan & 0 & 7.5 & 22.5 & 42.5 & 67.5 \\
7 & Daun Sirsak & 2.5 & 17.5 & 37.5 & 62.5 & 92.5 \\
8 & Daun Mimba & 5 & 17.5 & 40 & 67.5 & 97.5 \\
\hline
\end{tabular}

senyawa terpenoid. Menurut Afifah et al. (2015), terpenoid memiliki rasa yang pahit dan bersifat antifeedant yang dapat menghambat aktivitas makan serangga. Terpenoid juga bersifat sebagai penolak serangga (repellant) karena ada bau menyengat yang tidak disukai oleh serangga sehingga serangga tidak mau makan. Akibatnya larva $C$. formicarius mengalami kematian secara lambat karena kelaparan.

Senyawa aktif dari daun sirih hutan yang masuk ke dalam tubuh larva $C$. formicarius menyebabkan kematian secara lambat. Hal ini karena dalam pestisida nabati daun sirih hutan terdapat senyawa alkaloid. Alkaloid bertindak sebagai racun perut. Menurut Handayani et al. (2013) alkaloid yang terkandung dalam dalam daun sirih adalah arecoline. Arecoline bersifat nitrogenous pada makanan sehingga menetralisir asam lambung dan bekerja sebagai astringent yang dapat mengeraskan membran mukosa pada lambung.

Babadotan merupakan tumbuhan merupakan tumbuhan yang berbentuk herba yang banyak tumbuh di kawasan hutan sampai ketinggian 2.100 meter dpl. Daun Babadotan mengandung senyawa alkaloid dan flafanoid. Menurut Dinata (2007), flavonoid dapat dimanfaatkan sebagai bahan aktif dalam pembuatan insektisida nabati. Sedangkan alkaloid menurut Suryani (1991) dalam Sanyoto (2003), merupakan senyawa pahit dan beracun dapat menyebabkan rasa pusing dan tidak mau makan daun sawi disebabkan rasanya yang pahit dan akhirnya mati. Lebih lanjut Samsudin (2008), menyatakan bahwa kandungan aktif tanaman babadotan adalah saponin, flavanoid dan polifenol mampu mencegah hama mendekati tanaman (penolak) dan mampu menghambat pertumbuhan larva menjadi pupa. Pestisida nabati dapat mengendalikan serangan hama dan penyakit melalui cara kerja yang unik, yaitu dapat melalui perpaduan beberapa cara atau secara tungal. Cara kerja sangat spesifik yaitu: merusak perkembangan, telur, larva dan pupa, penolak makan, menghambat reproduksi serangga betina hama, mengusir serangga dan menghambat penggantian kulit serangga (Solikin, 2011).

Untuk mengurangi pemakaian insektisida sintetik, maka dilakukan pengendalian dengan penggunaan insektisida nabati. Penggunaan insektisida alami yang berasal dari ekstrak tanaman terbukti lebih aman karena mempunyai umur residu pendek. Setelah aplikasi, insektisida alami akan terurai menjadi senyawa yang tidak berbahaya bagi manusia dan lingkungan (Desi, 2007). Menurut Syahputra (2001), insektisida alami memiliki kelebihan tertentu yang tidak dimiliki oleh insektisida sintetik. Di alam, insektisida alami memiliki sifat yang tidak stabil sehingga memungkin dapat didegradasi secara alami. Selain dampak negatif yang ditimbulkan pestisida sintetik seperti resistensi, resurgensi dan terbunuhnya jasad bukan sasaran, dewasa ini harga pestisida sintetik relatif mahal dan terkadang sulit untuk memperolehnya. Di sisi lain ketergantungan petani akan penggunaan insektisida cukup tinggi. Alternatif yang bisa dilakukan diantara memanfaatkan tumbuhan yang memiliki khasiat insektisida, khususnya tumbuhan yang mudah diperoleh dan dapat diramu petani sebagai sediaan insektisida.

\section{KESIMPULAN}

Berdasarkan hasil penelitian maka dapat disimpulkan bahwa efektivitas pestisida nabati terhadap mortalitas hama Cylas formicarius tertinggi sampai terendah berturut-turut yaitu: daun mimba sebesar 97.5\%; daun sirsak sebesar 92.5\%; daun anona $87.5 \%$; daun sirih sebesar $82.5 \%$; daun babadotan sebesar $67.5 \%$; daun kenikir sebesar $47.5 \%$; dan daun pepaya sebesar $45 \%$.

\section{SARAN}

Berdasarkan hasil penelitian maka disarankan untuk menggunakan daun mimba, daun sirsak, daun anona, daun sirih, dan daun babadotan untuk mengendalikan hama Cylas formicarius karena mampu menyebabkan mortalitas larva di atas $50 \%$ pada kondisi laboratorium.

\section{UCAPAN TERIMAKASIH}

Penulis mengucapkan terimakasih kepada Kemenristek Dikti sebagai penyandang dana dalam kegiatan penelitian ini.

\section{DAFTAR PUSTAKA}

BPS TTS. 2014. Produksi Ubi Jalar di Kabupaten TTS. 
http://bps.go.id/ubijalar.php. Diakses 4 Maret 2015.

Brotodjojo, R. 2000. Pengaruh Konsentrasi estrak Biji Srikaya (Annona squamosa L.) Terhadap Mortalitas Hama Bubuk Beras (Sitophilus orizae L.). https://www.facebook.com/public/RukmowatiBrotodjojo. Diakses 29 Mei 2015.

Capinera, J.L. 2012. Sweetpotato Weevil, Cylas formicarius (Fabricius) (Insecta: Coleoptera: Brentidae (=Curculionidae)). https://edis.ifas.ufl.edu. Diakses 15 Maret 2014.

Cloyd, R.A. 2011. Pesticide Mixtures. M. Stoytcheva (Ed.) Pesticides-Formulations, Effects, Fate: 69-80. InTech Europe. University Campus STeP RiSlavka Krautzeka 83/A 51000 Rijeka, Croatia. Http://www.intechopen.com/ books/ pesticidesformulations-effects-fate/pesticide-mixtures. Diakses tanggal 12 Maret 2016.

Harpootlian, P. 2006. Species Cylas formicarius - Sweet Potato Weevil. http://bugguide.net.Diakses 2 Maret 2014.

Kalshoven, L.G.E. 1981. Pest of Crop in Indonesia. PT Ichtiar Baru-Van Hoeve. Jakarta.

Kardinan, A. 2005. Pestisida Nabati Ramuan dan Aplikasi. Penebar Swadaya. Jakarta.

Kardinan, A., 2008. Pengembangan Kearifan Lokal Pestisida Nabati. Sinar Tani Edisi 15-21 April 2009. No 3299. Tahun xxxix. Hal.5.

Kardinan, A. 2009. Pengembangan Kearifan Lokal Pestisida Nabati. Tabloid Sinar Tani. Edisi 15-21 April 2009
No. 3299 Tahun XXXIX. Jakarta.

Mulyaman, S., Cahyaniati, T. Mustofa. 2000. Pengenalan Pestisida Nabati Tanaman Holtikultura. Direktorat Jenderal Produksi Holtikultura Dan Aneka Tanaman. Institut Pertanian Bogor.

Nonci, N. 2005. Bioekologi dan Pengendalian Kumbang Cylas formicarius (Coleoptera: Curculionidae). http://pustaka.litbang.deptan.go.id. Diakses 10 Maret 2014.

Powell, K.S., A.E. Hartemink, J.F. Egenae, C. Walo, S. Poloma. 2001. Sweet Potato Weevil (Cylas formicarius) Incidence in the Humid Lowlands of PNG. www.alfredhartemink.nl. Diakses 21 Maret 2014.

Priyono, J., Y. Kusmayadi, E. Suryadi, H. Lanya. 2008. Hama Boleng (Cylas formicarius) pada Ubijalar dan Pengendaliannya. Dirjen Tanaman Pangan. http://www.deptan.go.id. Diakses 10 Maret 2014.

Samsudin, H. 2008. Pengendalian Hama Dengan Insektisida Botani. http://www.pertaniansehat.or.id

Shahid A.A., A.Q. Rao, A. Bakhsh and T. Husnain. 2012. Entomopathogenic Fungi As Biological Controllers: New Insights Into Their Virulence And Pathogenicity. Biol. Sci., Belgrade, 64(1):21-42, 2012. http://www.thejaps.org.pk. Diakses 4 Maret 2014.

Sukayat, D. 2010. Pemasyarakatan Pestisida Nabati Dalam Pengendalian OPT Pangan dan Holtikultura. Dinas Tanaman Pangan, Reaktikultur dan Percobaan Bidang Holtikultura. 